http://www.nauka-a-religia.uz.zgora.pl/images/FAG/2005-2006.t.2-3/art.10.pdf

William B. Provine

\title{
Projekt? Tak! \\ Ale czy inteligentny? ${ }^{*}$
}

Teorię inteligentnego projektu (ID - intelligent design) łatwo streścić w czterech punktach:

1. Obserwacja i analiza zjawisk naturalnych, rozciągająca się od astrofizyki, poprzez mikroorganizmy tu na Ziemi, po subatomowe właściwości chemiczne.

2. Odkrycie, że dana struktura jest „,nieredukowalnie złożona”.

3. Pierwszy wniosek: Inteligentny projektant stworzył ,nieredukowalnie złożoną" strukturę.

4. Drugi wniosek: Inteligentny projektant jest preferowanym przez badacza bogiem lub siłą działającą celowo. Rzecznicy teorii ID na ogół kwestionują to twierdzenie (ponieważ nie da się go dowieść), chociaż i tak przyjmują je na poziomie osobistym.

“William B. Provine, „Design? Yes! But Is It Intelligent?”, w: John Angus C Ampbell and Stephen C. Meyer (eds.), Darwinism, Design and Public Education, Michigan State University Press, East Lansing 2003, s. 499-512. Z języka angielskiego za zgodą Autora przełożył Sławomir PIEchaczek. Recenzent: Grzegorz NowaK, Zakład Biochemii UMCS, Lublin. 
Rzecznicy ID, których artykuły ukazały się w niniejszym tomie [Darwinism, Design and Public Education] wierzą, że chrześcijański Bóg stworzył struktury „nieredukowalnie złożone”, które nie mogą powstać w wyniku działania sił przyrodniczych. Zasługują zatem na miano kreacjonistów ID, w odróżnieniu od kreacjonistów młodej Ziemi, którzy twierdzą, iż chrześcijański Bóg stworzył nieredukowalnie złożone struktury biologiczne, jak również, że Ziemia liczy sobie nie więcej niż 10000 lat. Poglądy kreacjonistów młodej Ziemi opierają się na ich własnej interpretacji Biblii, świadectwach kopalnych, geologicznych śladach Wielkiego Potopu i wielu zastrzeżeniach wysuwanych przeciwko biologii ewolucyjnej. Obie grupy kreacjonistów są przekonane, że pewne elementy organizmów biologicznych zostały nadnaturalnie, inteligentnie zaprojektowane i że $\mathrm{z}$ istnienia „nieredukowalnie złożonych” struktur biologicznych można wywieść istnienie chrześcijańskiego Boga. Te dwie grupy kreacjonistów łącznie stanowią tylko niewielką część zwolenników ID.

Kto akceptuje teorię ID (lub jej mniej akademicko brzmiącą wersję)? Do tej pory Instytut Gallupa pięciokrotnie przeprowadzał ankietę, dotyczącą publicznych poglądów na temat ewolucji - w roku 1982 (przy okazji setnej rocznicy śmierci Karola Darwina), 1991, 1993, 1997 i 1999. ${ }^{1}$ Rezultaty są zbliżone, niemal nie do odróżnienia pod względem statystycznym.

- 47 procent badanych wierzy, że Bóg stworzył człowieka mniej więcej w jego obecnej formie w jednym momencie około 10000 lat temu.

- 40 procent wierzy, że człowiek powstał z mniej rozwiniętych form życia w procesie trwającym miliony lat, którym jednak kierował Bóg.

\footnotetext{
${ }^{1}$ Por. http://www.gallup.com/poll/releases/pr990830.asp.
} 
- 9 procent wierzy, że człowiek powstał z mniej rozwiniętych form życia w procesie trwającym miliony lat, jednak Bóg nie miał w nim udziału.

- 4 procent nie ma zdania.

Wydaje się, że trzecia możliwość uzyskała zbyt wiele punktów procentowych. Jeśli odejmiemy „,naturalistów”, którzy wierzą w inteligentny projekt, pochodzący z innego źródła niż „Bóg” (Tao i tak dalej), liczba prawdziwych naturalistów skurczy się do około 5 procent. Około 90 procent wybiera ID. Tak wygląda to w USA.

Co jednak z resztą świata? W zasadzie w każdym innym regionie zmniejszy się odsetek procentowy zwolenników pierwszego poglądu, że ludzie zostali stworzeni przez Boga około 10000 lat temu, lecz zarazem odpowiednio zwiększy się odsetek procentowy zwolenników poglądu drugiego, że „Bóg kieruje tym procesem” (jeśli będziemy brać pod uwagę również inne celowo działające istoty). Dlatego też mamy niewielką zmianę liczebności ogromnej większości, która wierzy w inteligentny projekt organizmów biologicznych.

Rozumowanie ID, lub może bardziej dokładnie - odczucie ID, jest kamieniem węgielnym wiary $\mathrm{w}$ boga lub przynajmniej $\mathrm{w}$ pewnego rodzaju inteligentnego projektanta. Żaden inny argument na rzecz istnienia boga nie jest bardziej przystępny czy przekonujący. Badania organizmów biologicznych, w tym ludzi, mają prowadzić bezpośrednio do przekonania, że zostały one inteligentnie zaprojektowane.

To przekonanie jest tylko pierwszym krokiem. Wszystkie inne przekonania wypływają dużo łatwiej $\mathrm{z}$ istniejącej już wiary w inteligentnego projektanta - życie po śmierci, podstawowe założenia etyki, ostateczny sens życia i wolna wola człowieka. Niewątpliwie jest to bardzo interesujące zagadnienie.

Przedwczoraj zatrzymali mnie w środku miasta Świadkowie Jehowy. Wiedzą, że jestem ateistą, a mimo to jesteśmy nastawieni do siebie przyjaźnie. Zatrzymują mnie zazwyczaj wtedy, kiedy mają coś 
dla mnie. Tym razem był to numer ich czasopisma Awake! [wydanie polskie: Przebudźcie się!] z 22 stycznia 2000 roku. Okładka przedstawiała młodą dziewczynę $\mathrm{z}$ wyciągniętą dłonią, a na wystawionym przez nią palcu siedział piękny motyl. Pismo było opatrzone tytułem „Life: A Product of Design" [Życie zostało zaprojektowane]. Pierwsze dwa artykuły szczegółowo wyjaśniały, czym jest ID - podając przykłady krokodylej skóry, pajęczych sieci, dzięciołów wytrzymujących uderzanie własnymi dziobami w drzewa, wydajności termodynamicznej kolibra, produkcji światła u świetlików i tak dalej. ${ }^{2}$

Co lub kto odpowiada za tak niezwykłe przystosowania? Odpowiedź na to pytanie znajdziemy w paragrafie pt. „Behind the Design - A Designer" [Ktoś musiał to zaprojektować!]. Opierając się na pracy i autorytecie Michaela Behe'ego (wliczając w to cztery cytaty z jego książki Darwin's Black Box [Czarna skrzynka Darwina]), Awake! konkluduje: „Czy wobec tego rozum nie podpowiada nam, że ten Ktoś ma również pewne zamierzenie w stosunku do ludzi? A jeżeli tak, to na czym ono polega? I czy możemy się czegoś więcej dowiedzieć o naszym Projektancie?" 3

W trzecim artykule pt. „The Great Designer Revealed” [Wielki Projektant daje się poznać], odkrywamy (niespodzianka!) obrazek przedstawiający otwartą Biblię oraz dwa inne, na których widnieją dzikie papugi i tropikalna ryba, opatrzone nagłówkiem: „Biblia i księga natury pozwalają poznać Wielkiego Projektanta". " Świadkowie Jehowy stanowczo odrzucają biologiczną ewolucję, wierzą jednak, że Ziemia jest stara, co odróżnia ich od kreacjonistów młodej Ziemi. Nakład Awake! sięga dwudziestu milionów kopii, jest wydawane w osiemdziesięciu trzech językach.

\footnotetext{
${ }^{2}$ „Naśladowanie cudów przyrody”, Przebudźcie się!, 22 stycznia 2000, s. 3; „Człowiek uczy się od przyrody", Przebudźcie się!, 22 stycznia 2000, s. 4-9.

${ }^{3}$ „Człowiek uczy się od przyrody...”, s. 9.

${ }^{4}$ „Wielki Projektant daje się poznać”, Przebudźcie się!, 22 stycznia 2000, s. 10-11.
} 
Teoretycy ID żyją w bardzo przychylnym im świecie. W Nowym Jorku, Hong Kongu czy pobliskich wsiach i miastach, prawie wszędzie co najmniej dziewięciu na dziesięciu ludzi myśli, że organizmy zostały zaprojektowane przez jakąś inteligencję. W niniejszej książce [Darwinism, Design and Public Education] zwolennicy „nowego" argumentu na rzecz ID nie występują przeciwko opinii publicznej, wprost przeciwnie - spotykają się z ogromnym, ogólnoświatowym poparciem.

Nurt kreacjonistów ID chce zachować dystans wobec bez porównania większej grupy kreacjonistów młodej Ziemi. Jednak z punktu widzenia ludzi przyglądających się temu wszystkiemu z zewnątrz, obie te grupy więcej łączy niż dzieli. Obie należą do kreacjonistów ID, choć jedna wierzy w starą, a druga w młodą Ziemię. Kreacjoniści młodej Ziemi uważają, że poświęcają więcej uwagi Biblii; podobnie czynią kreacjoniści ID, mimo że (w moim mniemaniu) nieco bardziej liberalnie. Kreacjoniści młodej Ziemi sądzą także, że z powodzeniem mogą uprawiać naukę. Nie są jednak zadowoleni z „wyniosłej” postawy kreacjonistów ID.

Kreacjoniści ID na ogół odrzucają teorię ewolucji przez dziedziczenie, choć mogą w pełni akceptować ideę doboru naturalnego. W swojej książce Sąd nad Darwinem, w większości poświęconej biologii, Phillip Johnson, uznawany za lidera ruchu ID, na argumentację przeciwko teorii ewolucji przez dziedziczenie przeznacza pięć rozdziałów (4-8). ${ }^{5}$ Krytykuje on przykłady ewolucji przez dziedziczenie, dotyczące wieloryba i skrzydeł ptaków, dając do zrozumienia, jakoby wieloryby i skrzydła stworzył chrześcijański Bóg. Chrześcijański Bóg mógł przecież kierować każdą częścią procesu ewolucji, jednak kreacjoniści ID wymagają, by ich inteligentny projektant tworzył po drodze ,pułapki na myszy”. "** William Dembski, Jonathan Wells, Paul

\footnotetext{
${ }^{5}$ Phillip E. Johnson, Sąd nad Darwinem, przeł. Robert Piotrowski, Oficyna Wydawnicza „Vocatio”, Warszawa 1997.

** (Przypis tłumacza) Jeden z teoretyków projektu, Michael J. Behe, używa przykładu pułapki na myszy dla zilustrowania problemu nieredukowalnej złożoności układów biochemicz-
} 
Nelson i inni autorzy w niniejszym tomie [Darwinism, Design and Public Education] odrzucają teorię ewolucji przez dziedziczenie i argumentują, że ewolucjoniści nie mają wystarczających świadectw, które by za nią przemawiały. Kreacjoniści ID i kreacjoniści młodej Ziemi nie różnią się od siebie tak bardzo.

Dlaczego zwolennicy teorii ID nieustannie kreują swój wizerunek nękanej mniejszości? Być może opinie filozofów, biologów ewolucyjnych, religijnych naturalistów metodologicznych (którzy uprawiając naukę, zachowują się jak naturaliści, lecz jednocześnie sami do końca ani naturalizmu, ani jego konsekwencji nie uznają), autorów naukowych podręczników, zwolenników zasady NOMA (S.J. Goulda „Nie zachodzące na siebie urzędy nauczycielskie” - Non-Overlapping MAgisteria) i przedstawicieli nauk humanistycznych liczą się dla teoretyków ID bardziej niż ogromne poparcie społeczeństwa.

\section{Ocena teorii inteligentnego projektu}

Jestem życzliwie nastawiony wobec tych, którzy wierzą w ID. Poczucie żalu odczuwane przez moich przyjaciół i studentów po dojściu do wniosku, że inteligentny projekt organizmów biologicznych nie istnieje, jest głębokie i nieraz bardzo trudne do zniesienia. Gdy znika wiara $\mathrm{w}$ ID, inne powiązane $\mathrm{z}$ nią wierzenia również tracą na sile: życie po śmierci i tak dalej. Studentom podejmującym kurs teorii ewolucji zawsze radzę, by uważnie strzegli swych poglądów na temat inteligentnego projektu organizmów biologicznych. Porzucenie ich pociąga za sobą szybkie skierowanie się ku naturalizmowi.

Teoria ID, w ramach ruchu ID, jest w zasadzie odmianą argumentu z „Boga ujawniającego się w lukach wiedzy”. Problem leży w tym, że owa postawa polega na ustawicznym wycofywaniu się, gdy „nieredukowalne” struktury zaczną być uznawane za „redukowalne”. Pla-

nych. 
toński Timajos stanowi bezpośredni argument na rzecz inteligentnego projektu niebios, Ziemi i organizmów biologicznych. Struktura i harmonia niebios czy organizmów wymagają istnienia inteligentnego projektanta. Galileusz, Kepler, Newton i wielu innych sławnych naukowców używało zasadniczo tego samego argumentu. W okresie od Platona do Newtona argument z ID mógł być stosowany do wielkiej różnorodności zjawisk niebieskich i organizmów.

Od czasów Newtona daje się zauważyć uderzający zanik oczywistych przykładów ID. Obecnie Michael Behe musi szczegółowo badać biochemiczne struktury w komórce w poszukiwaniu „nieredukowalnej złożoności" tego rodzaju, z jakim mamy do czynienia w przypadku pułapek na myszy. Jednakże wiele z jego przykładów nigdy nie znajdzie ostatecznego naturalistycznego wyjaśnienia $\mathrm{z}$ tego prostego powodu, że ścieżki prowadzące do tych struktur zostały pogrzebane $\mathrm{w}$ ciągu dwóch do trzech i pół miliarda lat ewolucji. Pojawi się jednak wiele prawdopodobnych scenariuszy, sugerujących możliwe naturalistyczne drogi przebiegu ewolucji.

$\mathrm{Na}$ zajęciach $\mathrm{z}$ teorii ewolucji regularnie przytaczam studentom, nie specjalizującym się w biologii, następujący cytat:

Prawdziwą trudnością dla teorii mechanistycznej jest to, że z jednej strony jesteśmy zmuszeni twierdzić, iż plazma zarodkowa jest mechanizmem o ogromnej złożoności i określoności, i - $\mathrm{z}$ drugiej - że ten mechanizm, pomimo swojej całkowitej określoności i złożoności, może rozdzielać się i łączyć z innymi podobnymi mechanizmami i może robić to w absolutnie nieograniczonym zakresie, nie zmieniając swojej struktury. Z jednej strony, powinniśmy postulować całkowitą określoność struktury, a z drugiej, jej całkowitą nieokreśloność. ${ }^{6}$

Następnie pytam studentów, co to za struktura, a oni jednogłośnie odpowiadają: DNA. Kolejny akapit brzmi:

\footnotetext{
${ }^{6}$ J.S. Haldane, Mechanism, Life and Personality. An Examination of the Mechanistic Theory of Life and Mind, John Murray, London 1914, s. 58.
} 
Nie ma potrzeby dokonywania dalszej analizy. Mechanistyczna teoria dziedziczności jest nie tylko nie udowodniona, ona jest po prostu czymś niemożliwym. Wiążą się z nią takie niedorzeczności, że żadna inteligentna osoba, która w pełni zdaje sobie sprawę ze znaczenia i implikacji tej teorii, nie może przy niej obstawać. ${ }^{7}$

Studenci są zdumieni. Kto to napisat? Autorem jest John Scott Haldane, znany psycholog i ojciec równie znanego ewolucjonisty J.B.S. Haldane'a. Napisał te słowa w 1914 roku.

Wychodząc od pojęcia genów, w pierwszej dekadzie dwudziestego wieku wielu naukowców sądziło, że zjawisko dziedziczności musi być „nieredukowalne”. Problem polegał na tym, że kwasy nukleinowe miały zbyt prostą strukturę, by stanowić materiał dziedziczności, natomiast białka okazywały się z gruntu do tego niedostosowane. Ten podstawowy materiał dziedziczności musiał jednak replikować się $\mathrm{w}$ szalenie szybkim tempie (aby to robić, powinien mieć prostą strukturę), a następnie przenosić bardzo skomplikowane informacje do organizmu (a więc musi być bardzo złożony). Przez ponad czterdzieści lat wielu naukowców podzielało pogląd J.S. Haldane'a.

Gdyby Michael Behe prowadził badania w 1914 roku, zjawisko dziedziczności prawdopodobnie również znalazłoby się na jego liście układów nieredukowalnie złożonych. DNA okazał się podstawą najbardziej materialistycznego, mechanistycznego systemu dziedziczenia, co przecież przewidywał J.S. Haldane, lecz uważał za niemożliwe. „Nieredukowalnie złożone” zjawisko przyrodnicze stało się częścią współczesnej materialistycznej nauki.

Być może ktoś mógłby mi wytłumaczyć, dlaczego nie widzę ID w organizmach biologicznych. Patrzę i patrzę, i nie znajduję ID, a to $z$ kolei wzmacnia me skłonności do ateizmu. Mimo to kreacjoniści ID potrafią zobaczyć ID tam, gdzie ja go nie widzę. Jeśli nadprzyrodzony projekt jest tak oczywisty, to dlaczego ja go nie dostrzegam? Przykła-

\footnotetext{
${ }^{7}$ Haldane, Mechanism..., s. 58.
} 
dy podawane w Rhetoric and Public Affairs (vol. 1, no. 4, czasopiśmie, na którym oparta jest ta książka), poza biologicznymi mechanizmami molekularnymi, o których mówi Behe, wydają się dość ogólnikowe i nieprzekonujące. Zwolennicy ID zadowalają się bezustannym cytowaniem Behe'ego. A przecież można by pomyśleć, że tom poświęcony ID zawiera bardzo wiele solidnych przykładów.

Dembski twierdzi, że argument z ID otwiera nowe perspektywy dla badań. Jego najlepszym przykładem jest na pozór selekcyjnie neutralne DNA, którego ogromna większość niczego nie koduje. W ramach ID naukowiec powinien wychodzić od założenia, że całe DNA jest funkcjonalne (Stwórca nie tworzy niczego, co byłoby bezużyteczne?). Wszyscy rzecznicy ID muszą sprzeciwiać się sformułowanej przez Kimurę teorii neutralnej mutacji/losowego dryfu, a nawet prawie neutralnej teorii ewolucji, której twórczynią jest Tomoko Ohta. Uważam, że tych dwoje wielkich rewolucjonistów wniosło największy wkład do ewolucyjnej biologii od czasów Karola Darwina, nawet jeśli w przypadku ssaków proporcje selekcyjnie neutralnego DNA wahają się od około 95 procent do 80 procent całości.

Możliwe, że Karol Darwin pomógł teoretykom ID, dostarczając im przykładów. Jego książka On the Various Contrivances by which British and Foreign Orchids are Fertilised by Insects [O różnych podstępnych sposobach zapylania storczyków brytyjskich i zagranicznych przez owady] jest wypełniona przykładami struktur kwiatów gwarantujących, że owady zostaną obsypane pyłkiem kwiatowym, a następnie oczyszczą się z niego, czego rezultatem będzie krzyżowe zapylenie rośliny tego samego gatunku. ${ }^{8}$ Wiele tych ,podstępów” nie tylko przywodzi na myśl pułapkę na myszy, ale cały owadzi system przystosowany do zapylania tylko jednego gatunku storczyka wydaje się mechanizmem ,nieredukowalnie złożonym”. Darwin postanowił zbadać te rośliny dokładniej, gdyż botanicy tradycyjnie opisywali je

\footnotetext{
${ }^{8}$ Charles DARWIN, On the Various Contrivances by which British and Foreign Orchids are Fertilised by Insect, and on the Good Effects of Intercrossing, 2nd ed., John Murray, London 1862.
} 
jako wytwór inteligentnego stwórcy. Oczywiście, Darwin sformułował wyjaśnienia. Opisał te mechanizmy jako „wspaniałe przystosowania”: „Kiedy tę lub inną część uznamy za przystosowaną do pewnego szczególnego celu, nie powinniśmy zakładać, że była ona pierwotnie zawsze utworzona dla tego jedynego celu. Zwykły bieg zdarzeń wygląda raczej tak, że część, która pierwotnie służyła jednemu celowi, w wyniku powolnych zmian przystosowała się do bardzo wielu odmiennych celów". 9

Aby odeprzeć naturalistyczne wyjaśnienia Darwina, ruch ID potrzebuje naukowca specjalizującego się w zagadnieniu zapylania storczyków. On, z kolei, powinien skontaktować się z zoologiem Douglasem Gillem (z University of Maryland), ekspertem od owadów zapylających storczyki.

W 1998 roku Edward Larson i Larry Witham przeprowadzili sondaż w National Academy of Sciences (USA); 95 procent biologów przyznało, że nie wierzy w żadnego celowo projektującego boga. Ogromna większość znanych mi ewolucjonistów nie wierzy w ID. Ja również. Nie dostrzegamy żadnych śladów ID w organizmach biologicznych lub tego, by procesem ewolucji kierowała inteligencja. Projekt istnieje, ale nie jest on inteligentny.

Ze względu na ograniczoną ilość miejsca, podam tylko jedną przyczynę odrzucania przeze mnie teorii ID (choć jest ich o wiele więcej). Inteligentny projektant nie jest wcale taki inteligentny. Poprosiłem Dave'a Raupa i Jacka Sepkopskiego o oszacowanie liczby gatunków kręgowców żyjących u schyłku okresu kredowego, około 70 milionów lat temu. Powiedzieli, że było ich mniej więcej 50 000. Następnie zapytałem, ile żyje obecnie. Odparli, że około 100 000. I rozstrzygające pytanie: ile gatunków kręgowców żyjących 70 milionów lat temu dało początek wszystkim żyjącym obecnie? Odpowiedzieli, że prawdopodobnie mniej niż 20, maksymalnie 25. A więc spośród około 50000 gatunków, wszystkie poza 25 wymarły. W okresie 70 milionów lat

\footnotetext{
${ }^{9}$ Darwin, On the Various Contrivances..., s. 282.
} 
większość gatunków kręgowców, które pojawiły się na Ziemi, również wymarła. Wynalazki rzekomo inteligentnego projektanta charakteryzują się niewielką trwałością.

A co z doborem naturalnym? Nie jest on mechanizmem, nie zachowuje się w żaden sposób, nie ma kształtu, nie jest przyczyną czegokolwiek. Biologowie są bardzo niedbali, jeśli chodzi o ich własny język, taki był również Karol Darwin. Dobór naturalny jest rezultatem bardzo złożonego procesu, który $\mathrm{w}$ gruncie rzeczy sprowadza się do dziedziczności, zmian genetycznych, ekologii i demografii. To, co się $\mathrm{z}$ tego procesu wyłania, nazywamy doborem naturalnym. Proces ten wyposaża organizmy w adaptacje, które pomagają im przetrwać i rozwijać się. Proces ów w zasadzie prowadzi również do wymierań, kiedy nastąpią dość duże zmiany środowiska. Można odnieść wrażenie, że inteligentny projektant nie ma zielonego pojęcia o zmianach środowiska. Jednakże zjawisko wymierania jest spodziewaną konsekwencją procesu tworzenia adaptacji. ${ }^{* * *}$ Jeśli dzięki żmudnym ćwi-

*** (Przypis recenzenta) Fragment ten wymaga komentarza. Otóż po pierwsze, dobór naturalny (dalej $\mathrm{DN}$ ) nie jest rezultatem złożonego procesu, tylko sam jest złożonym procesem myślenie o DN jako skutku jest wynikiem ukrytego myślenia teleologicznego, co w latach 70tych i 80-tych w ramach debaty o celowości w przyrodzie zostało przedyskutowane i odrzucone, a co być może nie jest znane Provine’owi, jako że dyskusje toczyły się głównie wśród filozofów biologii, a nie wśród biologów ewolucyjnych. Po drugie, proces ten nie wyposaża organizmów w żadne adaptacje - cechy, które w określonym środowisku sa adaptacjami, pojawiają się w wyniku zmian mikroewolucyjnych, głównie typu mutacji, u poszczególnych organizmów, zaś proces naturalnej selekcji, będący procesem makroewolucyjnym, powoduje, w wyniku zwiększonej przeżywalności i rozrodu organizmów posiadających cechy o wartości adaptacji, zwiększenie się w populacjach liczby organizmów te adaptacje posiadających i zmniejszenie liczby organizmów tych adaptacji nie posiadających (najczęściej szacuje się to zjawisko obliczając tzw. częstość genów w danej populacji). Krótko mówiąc, organizm wykazujący adaptację ma ją dlatego, że mieli ją rodzice (rodzic), a nie dlatego, że działał DN. Rodzice mieli tę cechę dlatego, że zaszła mutacja (zjawisko mikroewolucyjne), a nie dlatego, że w środowisku działa DN (proces makroewolucyjny). Po trzecie, proces DN do niczego nie prowadzi, nie jest ani ukierunkowany, ani tym bardziej celowy. Jego skutkiem są zmiany w składach populacji, jednak cechuje je zawsze opóźnienie w czasie - kolejne pokolenia organizmów są trochę lepiej zaadaptowane do warunków, w jakich lepiej niż organizmy niezaadaptowane przeżyli i rozmnożyli się ich rodzice. Jeżeli środowisko jest stabilne, to dobrze; jeżeli zmienia się, to może dojść do sytuacji, w której cechy będące u rodziców adaptacją są w kolejnym pokoleniu malaptacją, wobec czego następuje wymieranie. Oznacza to tyle, że wymieranie nie jest konsekwencją, „tworzenia” adaptacji, bo te powstają w wyniku zmian 
czeniom można wystąpić w Carnegie Hall, to dobór naturalny można pojmować jako żmudny proces demograficzny, którego rezultatem są wymierania.

\section{Naturalizm metodologiczny}

Musimy, przede wszystkim, objaśnić terminologię. Naturalista „metafizyczny” uważa, że wszystko, co odkryte przez człowieka, należy do sfery przyrodniczej, nie zaś - nadprzyrodzonej. Ten naturalizm nazwę naturalizmem „na każdą pogodę” (A-W - All-Weather). Naturalista „metodologiczny” uważa natomiast, że kiedy uprawia naukę, postępuje dokładnie tak jak naturalista „metafizyczny”; biorąc jednak pod uwagę modlitwy, moralne decyzje, wiarę w boga i tak dalej, powrót do nadnaturalizmu jest uzasadniony. To stanowisko będę nazywał naturalizmem ,na dobrą pogodę" (F-W - FairWeather). Kiedy zaczynają się kłopoty (np. czy będę istniał po śmierci?), naturaliści F-W znajdują schronienie w sferze nadprzyrodzonej. Naturaliści A-W muszą wtedy po prostu zacisnąć zęby i stawić czoła trudnym sprawom.

Badacze religijni mają problem. Dzisiejsi naukowcy, w odróżnieniu od naukowców sprzed ponad 150 lat, na ogół patrzą nieprzychylnym okiem na każdą formę aktywności czynnika nadprzyrodzonego w obrębie przyrody. W celu uzyskania akceptacji religijni naukowcy muszą uprawiać naukę bez jakichkolwiek wzmianek o

mikroewolucyjnych, tylko niezależnym od DN wynikiem zmian środowiskowych, które wpływają na procesy makroewolucji. Oczywiście, łatwo powiedzieć, że Provine pisze nie o DN, tylko o jakimś tajemniczym wielopoziomowym procesie, zachodzącym na różnych poziomach jednocześnie. Jednakże nazywanie procesem jednocześnie zmian poziomu molekularnego (genetycznych) i zmian poziomu ekologicznego, zupełnie od siebie niezależnych, o zupełnie różnych mechanizmach i ogromnie różnej złożoności systemowej, jest najdelikatniej to nazywając, nieporozumieniem - i w dodatku skutkiem tego procesu miałby być DN. Sądzę więc, że Provine ma na myśli jednak naturalną selekcję jako proces i mechanizm powodujący zmiany w częstości genów w populacjach, tyle że formułuje to dosyć swobodnie - i takiej interpretacji dotyczą moje uwagi. 
Bogu czy religii. By ominąć te przeszkody, wielu naukowców religijnych wybiera naturalizm F-W. Na gruncie nauki naturaliści F-W i AW są nie do odróżnienia.

Naturaliści F-W nie chcą znaleźć się w sytuacji, kiedy znajdą jakieś świadectwo na rzecz ID, a potem będą musieli się z tego wycofać. Chętnie też unikają wnioskowania o jakimś konkretnym bogu na podstawie ID w przyrodzie - dla zwolenników ID jest to temat krępujący. Dodatkową korzyścią jest dla nich ucieczka od miana „kreacjonistów”. Problem „Boga ujawniającego się w lukach wiedzy” zniknął. Jak widać, zalet naturalizmu F-W jest wiele.

Jednak zalety naturalizmu F-W nie powinny nam całkowicie przesłaniać jego wad. Stosowany przez ogromną większość ludzi na całym świecie argument $\mathrm{z}$ ID odchodzi w zapomnienie. Rezygnacja $\mathrm{z}$ niego jest wielkim ciosem dla poglądów religijnych.

Czy istnieje jakieś wyjście? Oczywiście. Naturaliści F-W wyrzekają się argumentu z ID. Nauka jest nauką. Naturaliści F-W mogą jednak boga lub celowość odkryć inną drogą, na przykład czytając religijne teksty, takie jak Biblia czy Chuang Tsu, osobiście doświadczając boga, wierząc $w$ autorytet innych lub używając zawiłego akademickiego argumentu na istnienie boga. Naturaliści F-W, którzy wierzą w boga, mogą w tajemniczy sposób wykrywać jego twory w przyrodzie. To tak, jakby można było zarazem zjeść ciastko i je mieć. Trudno uznać, by przyjmowanie ID i nie przyjmowanie ID było stanowiskiem spójnym.

Inny ważny problem związany z naturalizmem F-W polega na tym, że jest on po prostu starym naturalizmem A-W. Wszystko, do czego ma zastosowanie naturalizm A-W, podpada również pod naturalizm FW. Rozważmy następującą kwestię: czy Maryja urodziła Jezusa jako dziewica? Naturaliści A-W odpowiedzą: „Nie, ssaki nie rozmnażają się przez dzieworództwo, a nawet gdyby tak się rozmnażały, potomstwo byłoby tej samej płci. Przeprowadźmy test na ojcostwo i dowiedzmy się, kto naprawdę był ojcem". Naturaliści F-W mówią dokładnie to samo! Pójdźmy dalej: jak możemy wytłumaczyć istnienie 
bardzo religijnych ludzi? Naturaliści A-W powiedzą: „Prawdopodobnie religijne osoby dorastały słysząc każdego dnia o bogu. Myślą, że bóg przemawia do nich, możliwe też, że ludzie mają wrodzoną potrzebę boga i tak dalej”. I znów naturaliści F-W powiedzą to samo.

Naturaliści F-W mogą również wysunąć argument, że wydarzyło się kilka lub wiele cudów. Naturalista A-W powie wtedy do naturalisty F-W: „Proszę, nie nazywaj siebie naturalistą, ponieważ już nawet nie udajesz, że wierzysz w naturalizm”. Nic dziwnego, że sympatyzuję $\mathrm{z}$ teoretykami ID. Jeśli mają rację, to wierzenia ogromnej większości ludzi na Ziemi staną się uzasadnione. Jeśli zaś rację mają naturaliści F-W, wtedy ogromna większość ludzi okaże się najzwyklej oszukana, wliczając $\mathrm{w}$ to najważniejsze postacie $\mathrm{z}$ wielkich tekstów religijnych. Rzecznicy ID mają morze poparcia, natomiast rzecznicy naturalizmu F-W mogą cieszyć się poparciem wyłącznie pewnych wnikliwych studentów i profesorów.

\section{Stephen Jay Gould i zasada NOMA}

Steve Gould i ja zostaliśmy przyjaciółmi, odkąd spotkaliśmy się na konferencji na temat syntezy ewolucyjnej, zorganizowanej przez Ernsta Mayra w maju 1974 roku. Gould bardzo chwalił moją pracę z zakresu historii współczesnej biologii ewolucyjnej. Z kolei ja od dawna podziwiałem jego pracę naukową i byłem bardzo zirytowany faktem, że National Academy of Sciences tak bardzo ociąga się z wysłaniem mu zaproszenia do członkostwa. Był przewodniczącym American Association for the Advancement of Science (AAAS). Jestem również przekonany, że był bez porównania najbardziej wpływowym i powszechnie znanym historykiem nauki na świecie - mimo że większości $\mathrm{z}$ moich kolegów historyków nie podoba się taki punkt widzenia. Jego popularne eseje są międzynarodowym skarbem.

Jednakże na polu nauki i religii staliśmy na przeciwnych biegunach. W książce z 1999 roku, Skały wieków. Nauka i religia w pełni 
życia, Gould ogłosił swą zasadę NOMA. ${ }^{10}$ Zarówno nauka, jak i religia mają swoje własne sfery wpływów, które wzajemnie na siebie nie zachodzą. Innymi słowy, nauka i religia powinny zawsze być $\mathrm{z}$ dala od siebie, w ten sposób wszystkie sprzeczności między nimi zostaną wyeliminowane i będziemy żyli wszyscy razem w wielkiej harmonii. Według Goulda przyczyną problemów związanych z relacją nauki i religii jest niemal zawsze naruszenie zasady NOMA. Prawie wszyscy zgadzają się, że wielka harmonia w społeczeństwie należy do najwyższych naszych celów.

Jednym z ulubionych celów ataków Goulda było przekonanie o istnieniu inteligentnego projektu organizmów biologicznych. Rzecznicy teorii ID otwarcie sprzeniewierzają się zasadzie NOMA. Tak oto za jednym zamachem Gould odrzucił pogląd, za którym opowiada się jakieś 90 procent ludzkiej populacji na naszej planecie. Sam, oczywiście, zgadzam się z Gouldem w sprawie inteligentnego projektu organizmów, sadzę jednak, że konflikt miedzy nauką a religią jest czymś rzeczywistym. Rozwiązaniem Goulda było stworzenie zasady NOMA w nadziei na zapewnienie harmonii. Osobiście wolę spojrzeć na prawdziwy konflikt z góry i tą drogą dążyć do bardziej harmonijnych relacji społecznych.

Największy problem polega na tym, że zasada NOMA toleruje tylko niektóre rodzaje religii. W ten sposób prawie wszystkie religie świata musiałyby zrezygnować z najbardziej istotnych części swych własnych systemów wierzeń. Według Goulda dobrze jest wierzyć, że Bóg stworzył wszystkie stworzenia zgodnie z prawami nauki, lecz to jest w zasadzie deizm, który w czasach Izaaka Newtona uważano za pogląd ateistyczny.

Gould określa swe osobiste stanowisko jako „agnostyczne”, które - stosownie do zasady NOMA - jest stanowiskiem pojednawczym. Czy jednak traktował on swe własne naukowe teorie w podobny, agnostyczny sposób? Czy mówił on, że jest agnostyczny w stosunku

\footnotetext{
${ }^{10}$ Stephen Jay Gould, Skały wieków. Nauka i religia w pełni życia, przeł. Jacek Bieroń, Zysk i S-ka, Poznań 2002.
} 
do pojęcia przerywanej równowagi, jednej ze swoich ulubionych teorii? Nie, po przeanalizowaniu świadectw empirycznych z bardzo długiego okresu zauważył, że jego teoria jest dobrą pierwszą intuicją, hipotezą wyjściową. Przyjmujesz teorię, ale jako dobry naukowiec jesteś przygotowany na zmianę własnych zapatrywań, kiedy pojawią się świadectwa im przeczące. To dlatego traktuję agnostycyzm jako swego rodzaju wykręt. Ateizm jest mocną hipotezą wyjściową, ale powinniśmy go odrzucić, gdy świadectwo na rzecz istnienia boga będzie jednoznaczne. Gould, Thomas Henry Huxley (twórca tego terminu) i Karol Darwin uważali siebie za agnostyków, chociaż nie byli wierni agnostycyzmowi zastosowanemu do koncepcji doboru naturalnego. Gould zdawał się twierdzić, że religia jest dobra dopóty, dopóki nie daje się odróżnić od ateizmu w świecie przyrody. Mimo to Gould przez wiele lat występował przeciwko kreacjonistom. Napisał nawet artykuł wstępny w magazynie Science, oficjalnym czasopiśmie AAAS, w którym odniósł się do decyzji Szkolnej Rady Edukacji stanu Kansas z 1999 roku o usunięciu teorii makroewolucji ze stanowych testów egzaminacyjnych.

W Skalach wieków stanowisko Goulda wobec kreacjonistów młodej Ziemi jest niemal całkowicie nietolerancyjne. NOMA, zasada, która niesie ze sobą takie wartości jak poszanowanie, miłość, prostota, humanitaryzm, racjonalność, prowadzi Goulda do lekceważenia i uwłaczania połowie populacji Stanów Zjednoczonych. Mianuje on Karola Darwina największym rzecznikiem zasady NOMA. Bardzo długo walczył przeciwko naukowcom, którzy chcieliby świat wartości moralnych rozciągnąć na świat przyrody: „Jeden z najsmutniejszych rozdziałów w całej historii nauki stanowi nadużywanie danych w celu uzasadnienia domniemanych moralnych i socjalnych konsekwencji biologicznego determinizmu, twierdzenia, że nierówności opartych na rasie, płci lub przynależności społecznej, nie da się zmienić, ponieważ odzwierciedlają one naturalne, genetyczne uwarunkowania". ${ }^{11}$

\footnotetext{
${ }^{11}$ Gould, Skały wieków..., s. 122.
} 
Jednakże w O pochodzeniu człowieka Darwin obszernie pisze, że zjawiska społeczne i moralne podlegają procesowi doboru naturalnego, i analizował również dziedziczne różnice psychiczne pomiędzy mężczyznami i kobietami oraz różnice między rasami. ${ }^{12}$ Był on o wiele większym zwolennikiem dziedziczności w odniesieniu do ludzkich zachowań społecznych niż E.O. Wilson, częsty cel przytyków Goulda. Darwin dość wyraźnie naruszał zasadę NOMA. Fakt ten martwił Goulda, aczkolwiek w jego mniemaniu Darwin był zwolennikiem NOMA.

Mimo tych poważnych różnic w zapatrywaniach na naukę i religię, pozostaliśmy ze Steve'em przyjaciółmi. A co być może najważniejsze, zgadzaliśmy się w kwestii potrzeby bardziej ludzkiego, życzliwego społeczeństwa. Gould chciał się pozbyć wielu problemów dzięki zasadzie NOMA, ja natomiast wybrałem drogę rozpoznawania konfliktów między ludźmi oraz zbiorowy wysiłek mający na celu wypracowanie bardziej przyjaznego otoczenia, w którym życie nie traciłoby niczego ze swych uroków.

\section{Pedagogika w nauczaniu teorii ewolucji}

W 1999 roku Szkolna Rada Edukacji stanu Kansas podjęła decyzję o usunięciu teorii makroewolucji ze stanowych testów egzaminacyjnych i dała lokalnym zarządom, prowadzącym nadzór nad szkołami, prawo do decydowania, czy makroewolucja będzie przedmiotem wykładanym w szkołach okręgowych. Ewolucjoniści dysponują serwerem pocztowym, zwanym EvolDir. ${ }^{13}$ Ponad 90 procent zamieszczonych tam ogłoszeń to oferty pracy. Decyzja Szkolnej Rady Edukacji stanu Kansas wywołała na EvolDir falę szyderczych komentarzy. Sam przesłałem wiadomość następującej treści:

\footnotetext{
${ }^{12}$ Karol DARwin, O pochodzeniu człowieka, przeł. Stanisław Panek, Państwowe Wydawnictwo Rolnicze i Leśne, Warszawa 1959.

${ }^{13} \mathrm{http} / / /$ life.biology.mcmaster.ca/ brian/evoldir.html.
} 
Szanowni członkowie EvolDir,

Decyzja Szkolnej Rady Edukacji stanu Kansas jest prawdziwym darem dla nauczycieli biologii ewolucyjnej. Wreszcie zaczęliśmy rozmawiać o uwzględnieniu wszystkich uczniów na lekcjach biologii w szkołach średnich, zamiast ograniczać dyskusję wyłącznie do zagadnienia ewolucji naturalistycznej.

W społeczeństwie USA niemal 50 procent to kreacjoniści młodej Ziemi. Ogromna większość osób będących zwolennikami teorii ewolucji przez dziedziczenie wierzy, że procesem tym kieruje Bóg i że prawdziwa jest jedna z wersji ,teorii projektu”. W innych krajach istnieją dość liczne mniejszości, które żywią podobne poglądy. Czy naprawdę naszym celem może być uniemożliwianie uczniom z takimi poglądami uczciwego uczestnictwa w dyskusji na temat ewolucji na lekcjach biologii? Czy rzeczywiście wierzymy w to, że uczniowie zostaną przekonani do teorii ewolucji, gdy będziemy ich powstrzymywać od mówienia o ich własnych niepokojach dotyczących ewolucji?

Mamy już pełną kontrolę nad treścią teorii ewolucji w podręcznikach biologii dla szkół średnich. Nauczyciele zakazują uczniom na zajęciach uczciwej dyskusji na temat ewolucji. Co więcej, grono pedagogiczne jest do tego zachęcane przez National Academy of Sciences, National Center of Science Education (nasze ciało nadzorcze) i American Civil Liberties Union. ${ }^{14}$

W rezultacie studenci prawdopodobnie uważają teorię ewolucji za najnudniejszy temat na zajęciach z biologii. A przecież część zajęć poświęcona teorii ewolucji mogłaby być najbardziej pasjonująca, przyjemna i inspirująca.

„Nauczanie” kreacjonizmu czy teorii projektu jest całkowicie niepotrzebne i być może nielegalne w Stanach Zjednoczonych. Uczniowie będą poruszać wszystkie kwestie związane $\mathrm{z}$ teorią

\footnotetext{
${ }^{14}$ Por. „Teaching About Evolution and the Nature of Science”, http://www.nap.edu/read ingroom/books/evolution98/; http://fp.bio.utk.edu/darwin/NAS_guidebook/provine_1.html.
} 
ewolucji, jeśli zostaną do tego zaproszeni, a nie gaszeni. W Stanach Zjednoczonych i prawdopodobnie gdzie indziej w takich dyskusjach nie ma niczego bezprawnego. Uczniowie nigdy nie zapomną części zajęć dotyczącej teorii ewolucji i będą pamiętać o niej przez lata, a być może nawet przez całe życie.

Moja wypowiedź uzyskała niewielkie poparcie na stronie EvolDir, ukazało się natomiast kilka negatywnych komentarzy, pewne przesłano mi tylko prywatnie. Wielu ewolucjonistów było przerażonych moją propozycją, chociaż część wyrażała poparcie.

Eugene Garver wysunął w niniejszym tomie [Darwinism, Design and Public Education] argument na rzecz nie zapoznawania uczniów $\mathrm{z}$ teorią ID czy kreacjonizmem na zajęciach $\mathrm{z}$ teorii ewolucji. Być może prowadził on zajęcia dotyczące tej materii i odkrył, że powstrzymywanie większości studentów od udziału w nich jest dobrym podejściem. Jeśli miałbym prowadzić zajęcia zgodnie $\mathrm{z}$ jego wyobrażeniami, natychmiast bym zrezygnował. Bez udziału uczniów, bez brania pod uwagę ich własnych poglądów i przyjmowania dotkliwej (choć dyktowanej osobistymi przekonaniami) krytyki, nauczanie jest pozbawione sensu. Przekazywanie wiedzy jest nudne. W takim wypadku lepiej dać uczniom książki.

Nauczałem teorii ewolucji wszędzie, począwszy od gimnazjum (przez dwa lata), liceum (dziewięć liceów w północnej części stanu Nowy Jork), a skończywszy na poziomie uczelni wyższej, studiów podyplomowych czy letnim uniwersytecie dla dorosłych. W każdym przypadku uczniowie świetnie się bawili, podzielając i krytykując poglądy lub świadectwa, dotyczące teorii ewolucji. Nawet w ramach 400-godzinnego kursu cotygodniowe sekcje, liczące nie więcej niż 20 godzin, dają studentom okazję do poważnych dyskusji. Sądzę, że dużo uczymy się na temat biologii ewolucyjnej, od teorii Darwina do koncepcji współczesnych, i mamy $\mathrm{z}$ tego wiele radości. Każdy, kto prezentuje odmienny punkt widzenia, jest mile widziany. Celem nie jest napełnienie uczniowskiej mózgownicy tym wszystkim, co obecnie 
uważa się na temat biologii ewolucyjnej, ale to, by zainteresować ucznia problematyką ewolucyjną na całe życie. Pozwolę sobie przedstawić złożoność zajęć w liceum.

Zajęcia $\mathrm{z}$ biologii $\mathrm{w}$ małym liceum zaczynają się od części poświęconej teorii ewolucji. Nauczyciel postępuje wedle rad Garvera. Uczniowie będący Świadkami Jehowy wiedzą znacznie więcej na temat ewolucji niż ich rówieśnicy i są pewni, że ona nie miała miejsca. Świadkowie zaczynają myśleć nad ewolucją w bardzo wczesnym wieku. Na zajęciach są już gotowi, by o niej rozmawiać. Dokładnie tak, jak podejrzewali, nauczyciel stara się im zamknąć usta. Twierdzi, że najpierw muszą się nauczyć teorii ewolucji w tej postaci, jaką się wykłada w podręczniku, zatwierdzonym przez naukowców i National Academy of Sciences. Mogą wierzyć w cokolwiek chcą, ale muszą zapoznać się z ogólnie przyjętą wiedzą. A ogólnie przyjętą wiedzą są pewne, ale nudne informacje o biologii ewolucyjnej, przedstawiane $\mathrm{w}$ podręczniku. Następne zajęcia biologii tracą to radosne podniecenie, któremu sprzyja wolna dyskusja na temat ewolucji. Na jaw wychodzi niesprawiedliwość.

Przypatrzmy się innemu podejściu. Nauczyciel sądzi, że teoria ewolucji należy do ważnych tematów - według niego wszyscy uczniowie powinni być nią zainteresowani. Wszystkie prezentowane stanowiska są przedmiotem dyskusji i krytyki. Świadkowie Jehowy przedstawiają swoje argumenty przeciwko teorii ewolucji. Do dyskusji przyłączają się ewolucjoniści, którzy wierzą, że Bóg kieruje procesem ewolucji, uczniowie opowiadający się za naturalizmem oraz osoby żywiące inne poglądy. Wtedy nauczyciel mówi: „Jak dotąd, toczona przez was dyskusja przebiega prawidłowo. Teraz udajcie się do pracowni komputerowej i wyszukajcie w Internecie więcej informacji na temat ewolucji, by odpowiednio przygotować się do jutrzejszych zajęć" - poświęconych tematowi doboru naturalnego, pojęcia gatunku, rozmieszczenia geograficznego, losowego rozprzestrzeniania się genów lub jakiemukolwiek innemu tematowi, który zaproponuje nauczyciel. Uczniowie są zachwyceni, ponieważ zostają wysłuchani i 
potraktowani poważnie. Uczniowie, będący zwolennikami kreacjonizmu, mogą iść do domu i powiedzieć mamie i tacie: „Szkoda, że nie widzieliście, jak dziś dołożyłem ewolucjonistom". Żadni rodzice nie będą rozczarowani, jeśli ich dzieci będą stwarzać innym i sobie okazję do rozmowy i uczestnictwa.

Dopuszczając wszystkich uczniów do udziału w dyskusjach, sprawiamy, że analizowanie teorii ewolucji na zajęciach w liceum przestaje być czynnością niebezpieczną. Przez ponad 30 lat niejeden rodzic miał zastrzeżenia do tego podejścia. Jednak zajęcia są fascynujące, a uczniowie i nauczyciele liceów przesyłają wyrazy wdzięczności.

Rozważanie sposobów zapobiegania uczestnictwu młodzieży w pewnych zajęciach, przy równoczesnym faworyzowaniu innych, jest dogłębnie niesprawiedliwe. Wiele stanów sugeruje trzymanie kreacjonistów z dala od dyskusji na lekcjach biologii. Wyżej wspomniana broszura National Academy of Sciences daje wskazówki, jak to robić. Ale postrzeganie połowy lub więcej swoich uczniów jako „wrogów” jest upiorne.

Kreacjoniści będą musieli bardziej stanowczo głosić swoje poglądy. Podtrzymuję swoje poparcie dla tych, którzy chcieliby, aby ich głos został wysłuchany na zajęciach biologii. Będę popierał starania mające na celu ograniczenie nauczania biologii ewolucyjnej dopóty, dopóki ewolucjoniści nie zachęcą uczniów do udziału w dyskusjach. Pomysł American Civil Liberties Union, by współpracować z biologami ewolucyjnymi w celu ograniczenia wolności słowa większości licealistów w tym kraju, jest groteskowy. 